\title{
An architectural evaluation method for conservation of traditional dwellings
}

\author{
Başak İpekoğlu* \\ Department of Architectural Restoration, Faculty of Architecture, Izmir Institute of Technology, 35430 İzmir, Turkey
}

Received 17 March 2004; received in revised form 6 January 2005; accepted 7 February 2005

\begin{abstract}
Historic urban sites and traditional houses are the most important evidence of the past life style. The conservation of these traditional values in the context of conservation and revitalization of architectural heritage is in a sense the preservation of culture. The main goal of conservation is to enliven cultural properties by evaluating their architectural, historical, environmental, visual and aesthetic characteristics. These evaluation studies, which are essential in the context of conservation plans, are inevitable phases to determine the principles of the plans. This study is aimed to propose a method for the architectural evaluation phase, which is essential before conservation decisions. The proposed method is based on a gradation system. Odunpazarı district in Eskișehir/ Turkey is determined as the area to test this gradation method. It is proposed that this method explains the systematic way for evaluating architectural features belonging to historic sites whose conservation plans are to be prepared. In the study, traditional buildings are evaluated from the point of their exterior and interior architectural characteristics and classified as different value groups: A, B, C and D. This grouping will be advantageous to conservation decisions. Different technical teams may be organized to be responsible for these various value groups. As a result, a systematic approach for the determination of specialized teams and required equipment will be achieved. Thus, an accurate determination of required time and cost estimates will be realized.
\end{abstract}

(C) 2005 Elsevier Ltd. All rights reserved.

Keywords: Cultural heritage; Classification; Decision support; Heritage conservation management; Analysis; Conservation planning; Traditional dwellings; Architectural evaluation

\section{Introduction}

The main aim of historical urban conservation is to take measures for the conservation of the historical environment, which will continue its existence by reconciling the past and the future and by not losing its historical appearances. It can be clearly determined that in various earlier researches, the subject is examined in multidimensional approaches within the framework of these measures [1-4]. In the context of these approaches, the importance of the conservation of physical characteristics is emphasized together with cultural, social and economic aspects [5-7]. Depending on the previous researches, the frame of this research

\footnotetext{
*Fax: + 902327507012.

E-mail address: basakipekoglu@iyte.edu.tr.
}

was determined by examining the subjects of conservation plans in general.

In urban conservation studies, it is necessary to consider the factors which cause towns or sections of towns to be considered as peculiar settlements, and produce the circumstances of its formation. Consequently, the agents which form its identity as a united end result of cultural, social and economic features must be conceived. This way of thinking brings into mind that the subjects which will be preserved are not only physical characteristics. Therefore, it is obvious that the models related to the social and economic structure are necessary for conservation plans, besides the conservation projects oriented towards physical characteristics [8-10]. While developing conservation decisions, the important subjects are who will be affected and which user group will be involved. An approach, 
which gives priority to the physical appearances of conservation and makes the inhabitants suffer from the results of conservation, is considering the conservation plan in a limited vision. In the areas, which will be preserved besides physical decisions, it is necessary to take economic measures which will make them valid and realistic and will make possible the social conditions that are aimed for. All of these are well known and have been noted in previous researches [11-13].

On the other hand, the production and implementation methods of the conservation plan have the responsibility of preventing the provocation of destruction in place of conservation. During the realization of the decisions, while reviving the historical environment, the reality which is regarded in all circumstances is to prevent the destruction of architectural properties in place of conservation in the interventions. The evaluation of the physical properties of the historic fabric one by one is among the subjects, which have a great role in the success of the conservation plan $[14,15]$.

In this framework and in the limits of this special study, it is aimed to pay attention to the technical evaluation of architectural characteristics in the production of the plan rather than to start a theoretical argument related with conservation. With this approach, it is developed in the form of the detailed evaluation of one of the subjects, which should be considered in the conservation plans. In this study, a method for architectural evaluation phase preceding decisions for conservation is proposed with the concern of prevention of destruction of architectural characteristics in the name of conservation.

\section{General visual and architectural characteristics of the study area}

This study is generated in the context of the available data obtained from a certain traditional historic site Odunpazarı District, Eskișehir, in Turkey. Eskișehir is located in central Anatolia, with a medium-sized historic district. This town was established during the later part of the medieval period [16-19], but it flourished during the nineteenth century with the development of new districts composed of large- and small-sized mansions, constructed in timber-framed, mud-brick in-fill. These new districts were designed to serve the population rise that the town faced due to migration. The later part of the twentieth century brought another vital change for the urban development of the town, following the establishment of new Universities, which caused the increase of a young student body. To answer their needs, renovation and/or new housing projects began to be initiated which had a negative effect on the historic fabric and on the houses that were designed according to the needs and requirements of the nineteenth century.
Odunpazarı is the only area in Eskişehir where traditional neighbourhood characteristics are still concentrated. Kurşunlu Külliye, the landmark of the area was built in 1516 and gives evidence that the area was an important settlement during the Ottoman Period. The houses, which are in the majority and have traditional architectural characteristics in their facade orders and architectural elements, were constructed with timberframed construction system (Figs. 1 and 2). This structural system consists of three sections, which are masonry base, timber-framed upper section and timber roof section. Foundations and basement floor were built with rubble stone or mud-brick with horizontal timber beams. The timber-framed upper section was formed of horizontal, vertical and diagonal elements, which constituted continuous panels and boxes [20]. Mud-brick was used as an infill material and the walls were finished with mud or lime plaster and whitewashed. In the site, the buildings are two or three storied. They are situated directly on streets or in gardens. They are either single or row houses and there are also twin houses. Projections

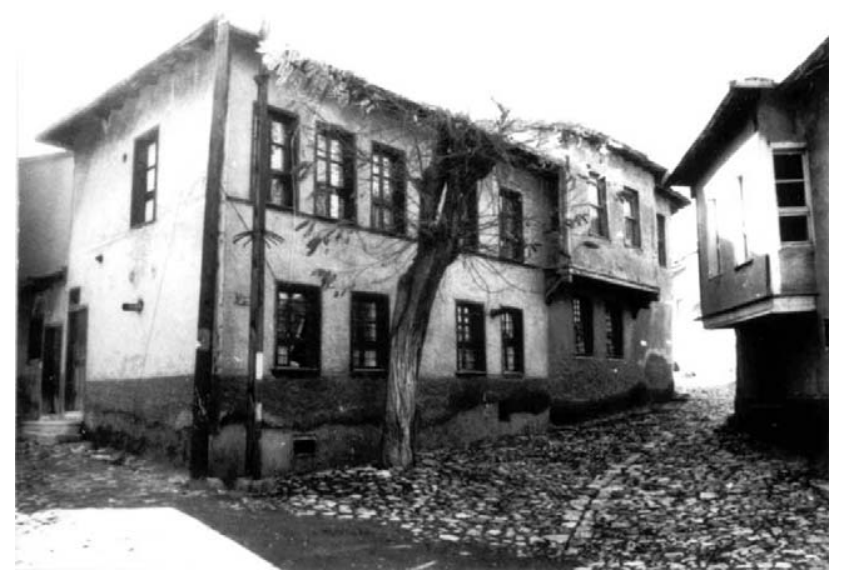

Fig. 1. Traditional houses give important vistas.

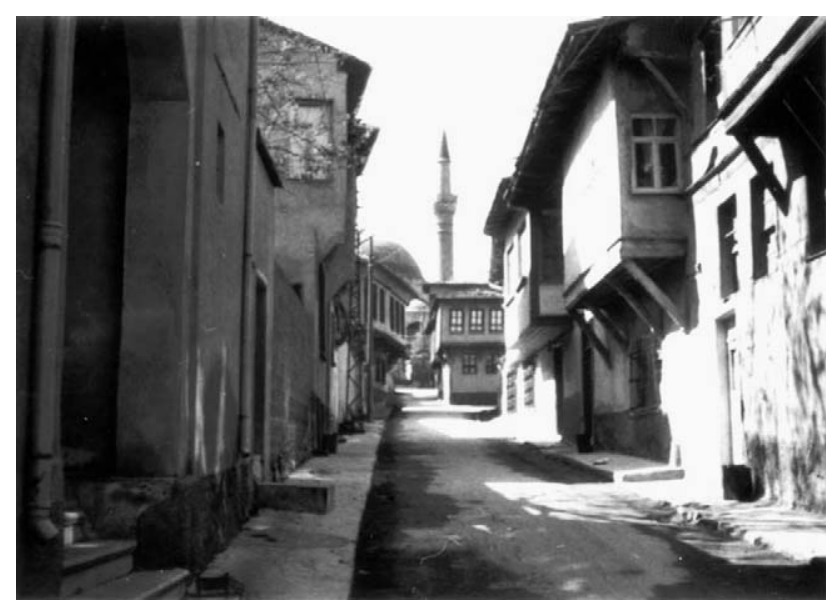

Fig. 2. Buildings with traditional architectural characteristics. 
of some houses in street corners are built on the corner so as to increase the value of the streets as well as the buildings. The houses in gardens are separated from the street by garden walls. However, the upper floors of most of them contribute to the general appearance of the street. Garden walls are constructed of mud-brick and traditional types are mud plastered but not whitewashed. Iron bars and lattices are generally seen in ground floor windows. In addition, pediments, profiles below pediments, consoles and supports below projections, timber elements above and below windows and concave eaves are remarkable architectural elements of these traditional houses. Location of the houses defines the street characteristics. Streets offer rich perspectives with traditional houses, which have projections (Fig. 3). The squares, to which streets open, are the important elements of the area. Most of them are surrounded by

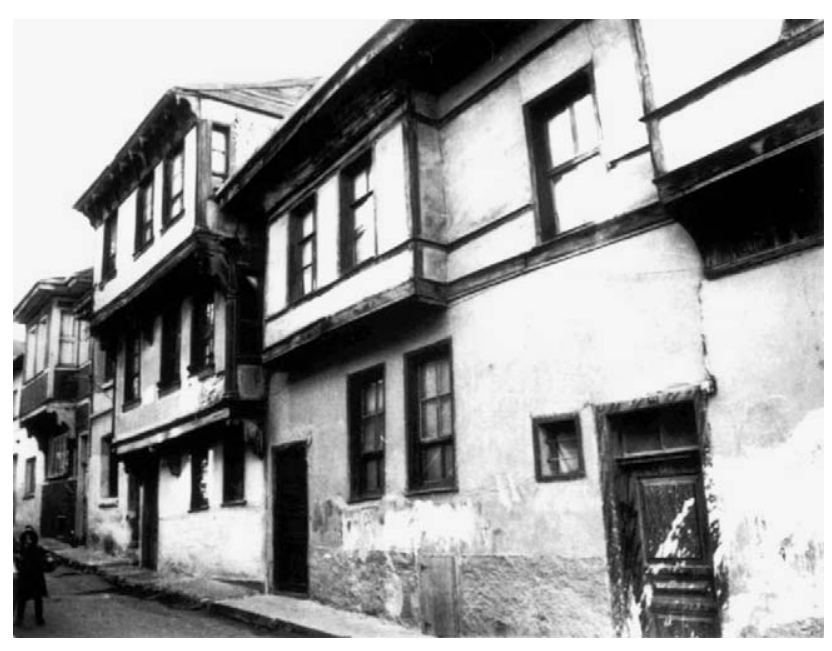

Fig. 3. Streets offer rich perspectives with traditional houses which have projections.

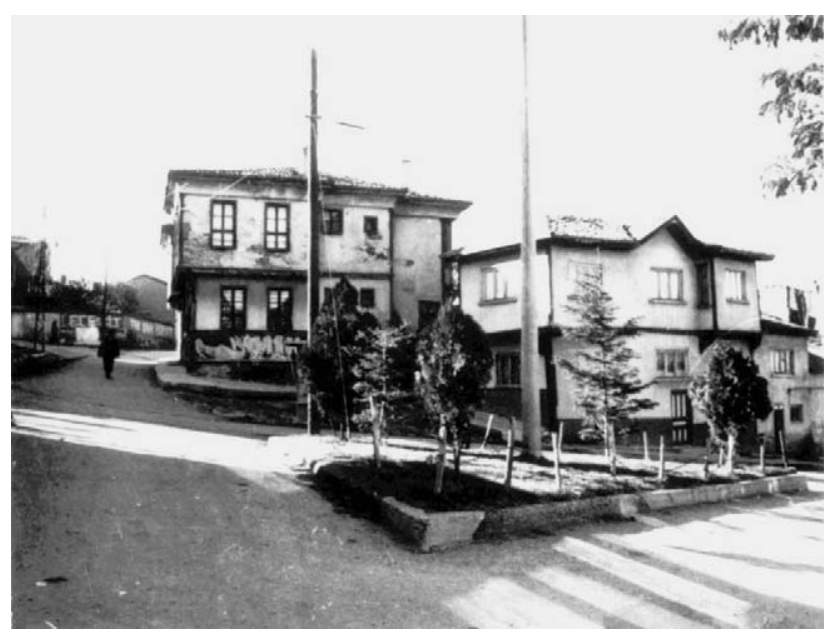

Fig. 4. Squares are surrounded by traditional houses.

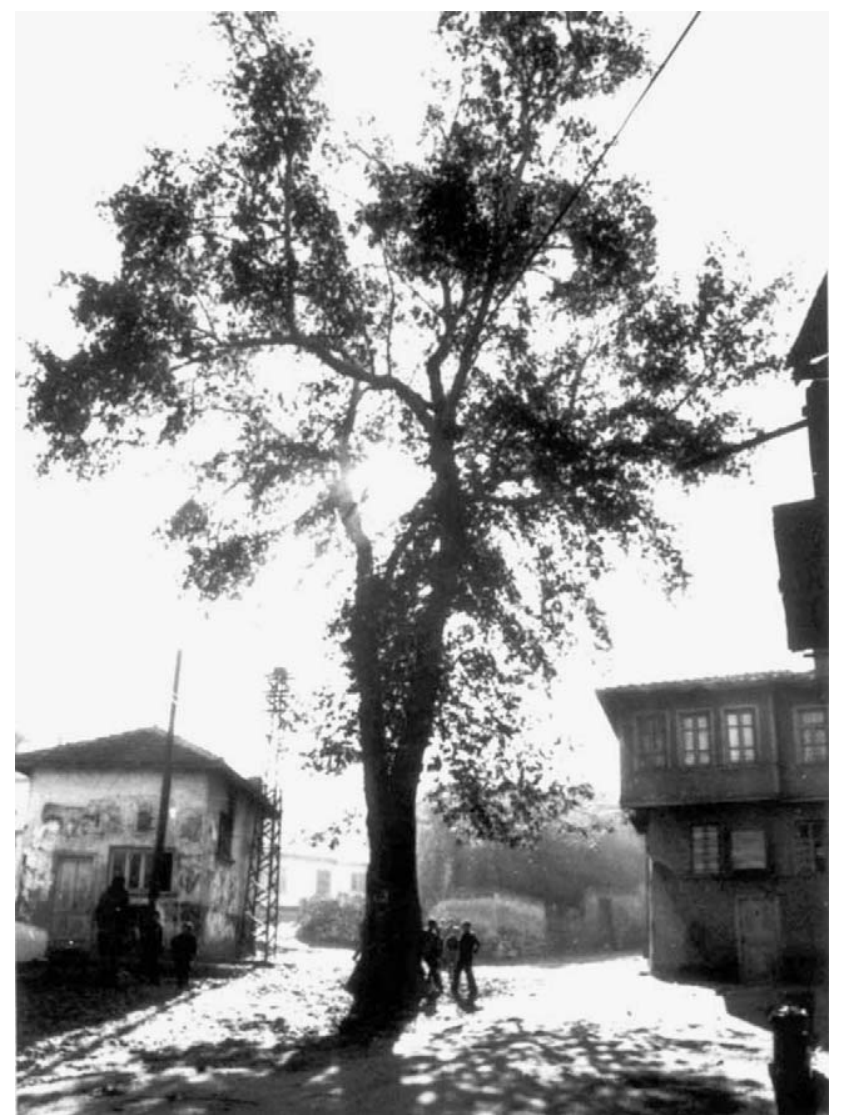

Fig. 5. Squares have important visual effects.

traditional houses and have important visual effects upon entering the area (Figs. 4 and 5).

The architectural and social analyses of the traditional houses in the area were realized in an earlier study [21]. Therefore, the concern of this paper is to contribute to the architectural evaluation of the traditional houses with a methodical approach.

\section{Methodology of gradation of the traditional dwellings in architectural evaluation}

Traditional dwellings are evaluated from the point of their exterior and interior architectural characteristics. Since interior studies about all the traditional houses are not possible, the exterior and interior characteristics are taken into account separately in the architectural evaluation. While 133 traditional houses are evaluated from the exterior, only 58 are evaluated from the interior.

\subsection{External evaluation}

In the external evaluation (Table 1), the degree of alteration, facade types, facade elements and contribu- 
Table 1

The criteria and the grades for the external evaluation of traditional houses

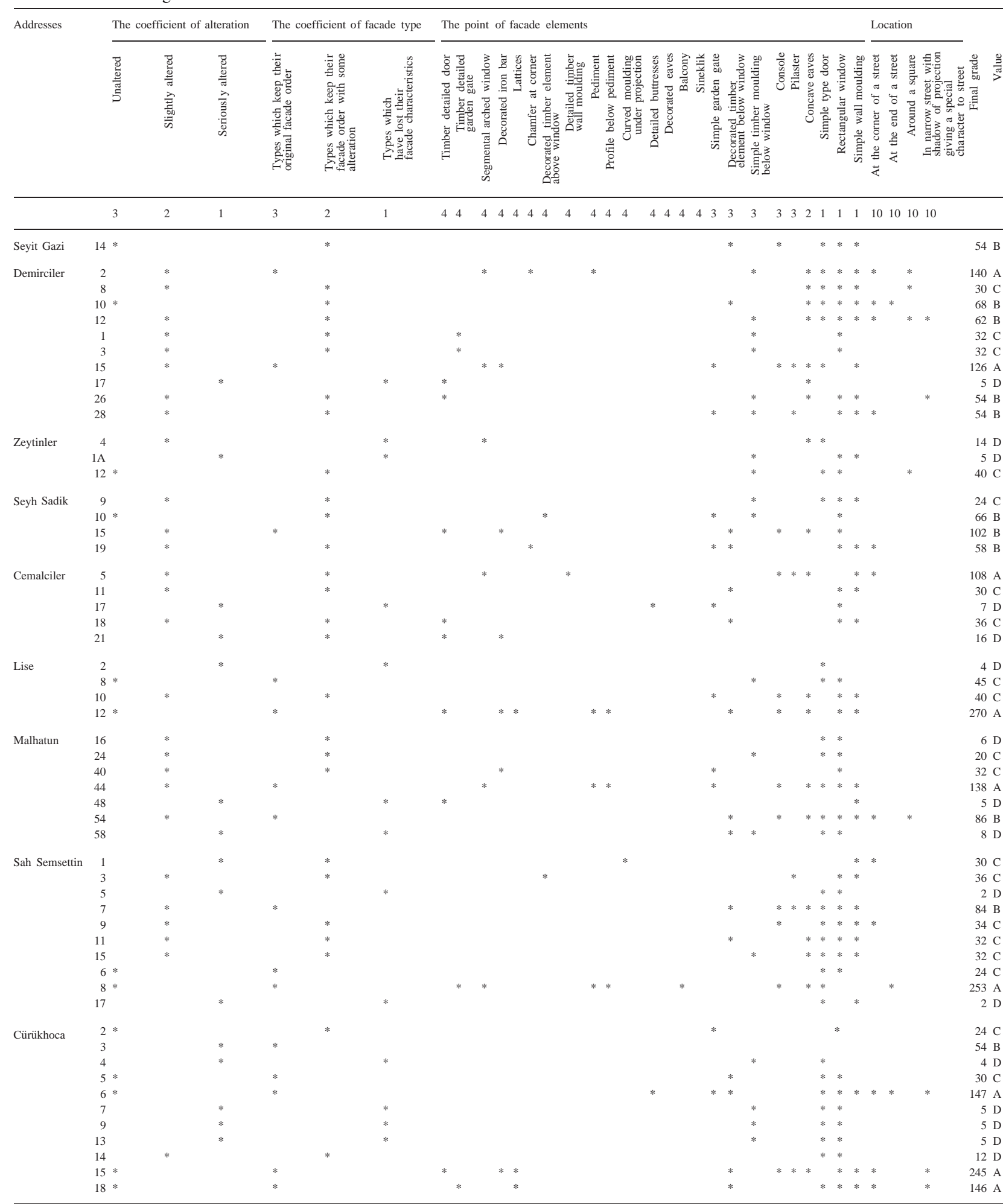

tion of the houses to the street with their locations are taken into consideration. The coefficients related to the degree of external alteration and facade types are multiplied by the point of facade elements. If the house has an environmental value as regards its location, 10 points are added to the obtained value.

External evaluation $=\left(C_{\mathrm{a}} \times C_{\mathrm{f}} \times P_{\mathrm{e}}\right)+10$, 
where $C_{\mathrm{a}}$ is the coefficient of alteration, $C_{\mathrm{f}}$ is the coefficient of facade type, $P_{\mathrm{e}}$ is the point of facade elements, and 10 is the point of location.

Gradation of the external alteration: The coefficient of three is given to unaltered houses, the coefficient of two is given to slightly altered houses, and the coefficient of one is given to seriously altered houses.

Gradation of facade type: The combination of the traditional architectural elements gives certain traditional facade typologies. Any facade type, which is in the traditional style, is taken into evaluation. However, houses that perfectly present the facade types examined, are given priority. Therefore, the coefficient of three is given to buildings that keep their original facade orders, the coefficient of two is given to buildings that keep their facade orders with some alterations, and the coefficient of one is given to buildings that have lost their facade characteristics.

Gradation of facade elements: All the traditional elements are graded. High grades are given to the traditional elements seen rarely and lower grades are given to the common traditional elements. Being rare was evaluated as a positive factor because some of these elements exhibit detailed workmanship and some of them create a rich facade order, together with the common facade elements. Four points are given to elements which exist on not more than 16 houses: timber detailed door in 16 houses, decorated iron bar in 15 houses, segmental arched window in 10 houses, pediment in 9 houses, detailed supports in 8 houses, decorated timber element above window in 8 houses, curved moulding under projection in 7 houses, timber detailed garden gate in 5 houses, profile below pediment in 5 houses, lattices in 5 houses, chamfer at corner in 3 houses, detailed wall moulding above upper floor in 3 houses, balcony in one house, 'sineklik' (a space on the roof where in hot summer nights, men sat and chatted) in one house and decorated eaves board in one house. Three points are given to elements which exist in approximately 17-23 houses: simple timber moulding below window in 33 houses, console in 31 houses, decorated timber element below window in 28 houses, simple garden gate in 26 houses and pilaster in 19 houses. Two points are given to elements that exist in approximately 34-50 houses: concave eaves in 40 houses. One point is given to elements that exist in houses more than 51: regular window in 109 houses, simple wall moulding in 84 houses and simple type door in 72 houses.

Gradation of location: The locations of some houses are important within their environment. Buildings at the corner of a street, at the end of a street or around a square have special characteristics. Furthermore, in narrow streets, buildings following the street line give a special characteristic to the street with shadows of their projections on upper floors and eaves. Therefore, the characteristic locations of these buildings are taken into consideration giving them 10 points.

Consequently, if the final grade is between 0 and 15 , the house is classified in D group (Fig. 6); between 16 and 50, in C group (Fig. 7); 51-105, B group (Figs. 7 and 8); 106-270, in A group (Figs. 9 and 10) in its external architectural value.

\subsection{Internal evaluation}

In the internal evaluation (Table 2), if one of the classic plan types is seen in the house, 10 points are added to the coefficient related to the internal alteration of the house (if the classic hall is in corridor form, instead of 10 then 5 points are added) and this is multiplied by the point of plan elements; thus, the internal evaluation of the house is obtained.

Internal evaluation $=\left(C_{\mathrm{a}}+P_{\mathrm{t}}\right) P_{\mathrm{e}}$,

where $C_{\mathrm{a}}$ is the coefficient of alteration, $P_{\mathrm{t}}$ is the point of plan type, and $P_{\mathrm{e}}$ is the point of plan elements.

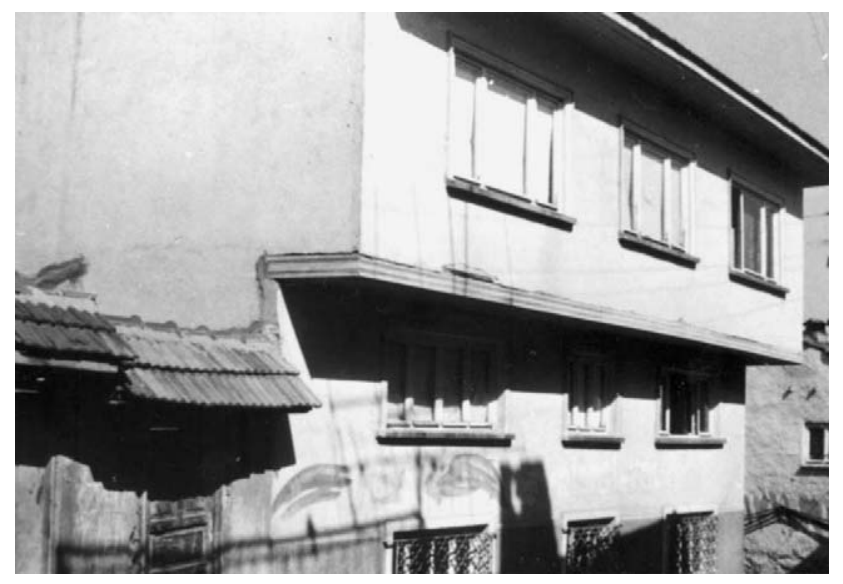

Fig. 6. A house in group " $D$ ".

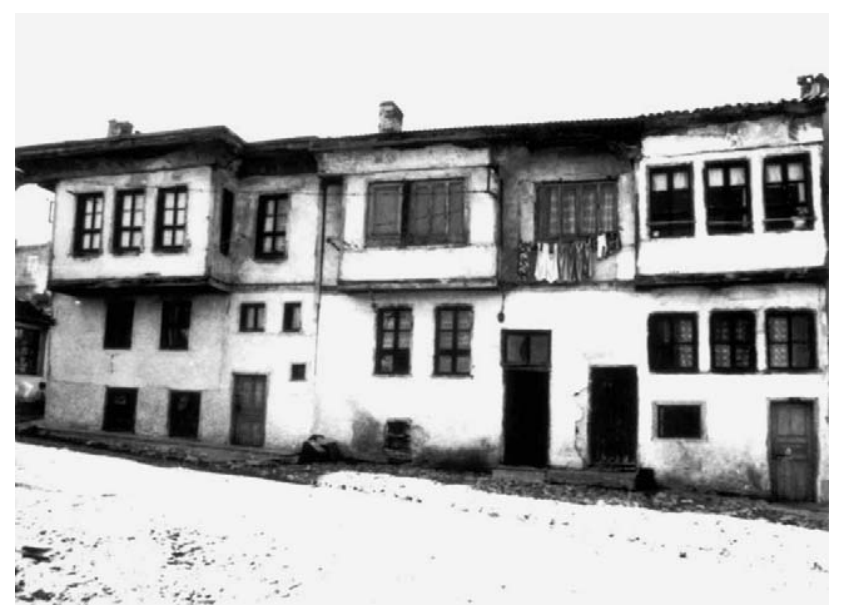

Fig. 7. A house in group " $\mathrm{C}$ " at the right and a house in group "B" at the left. 


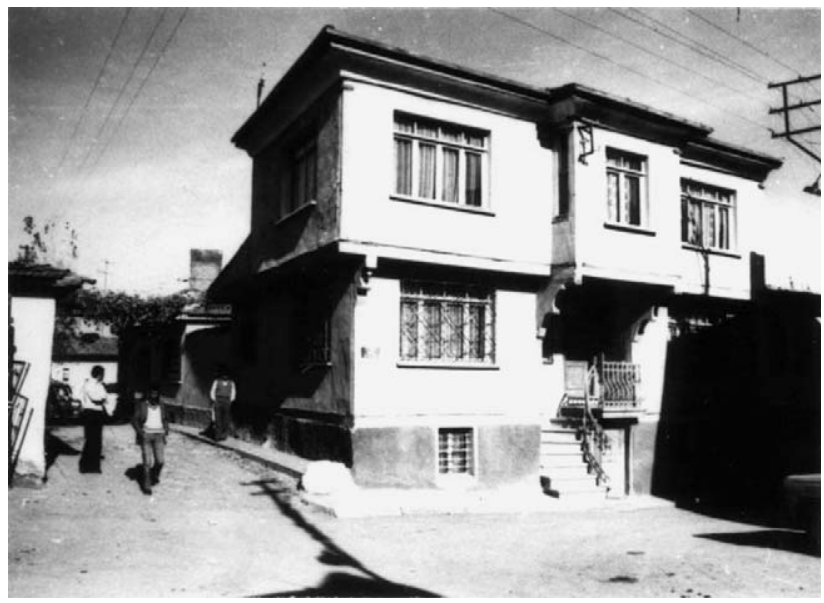

Fig. 8. A house in group "B".

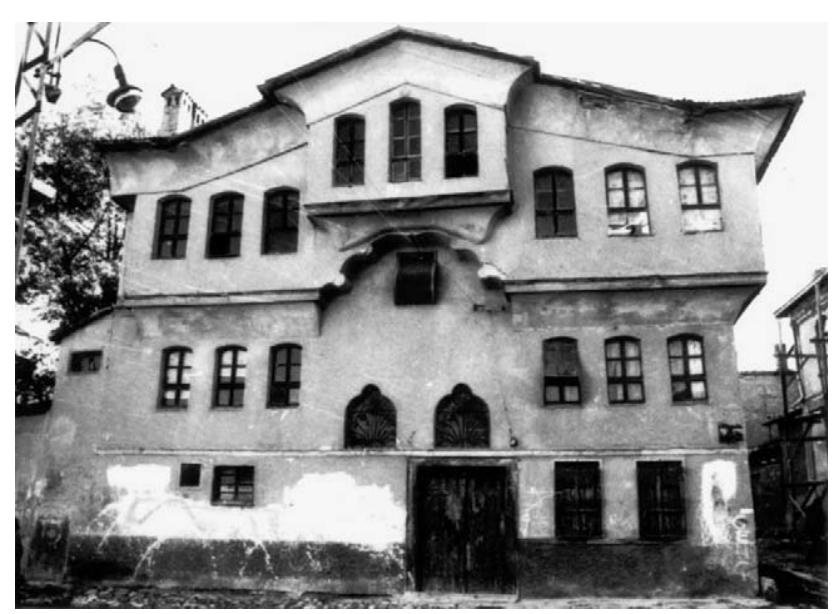

Fig. 9. A house in group "A".

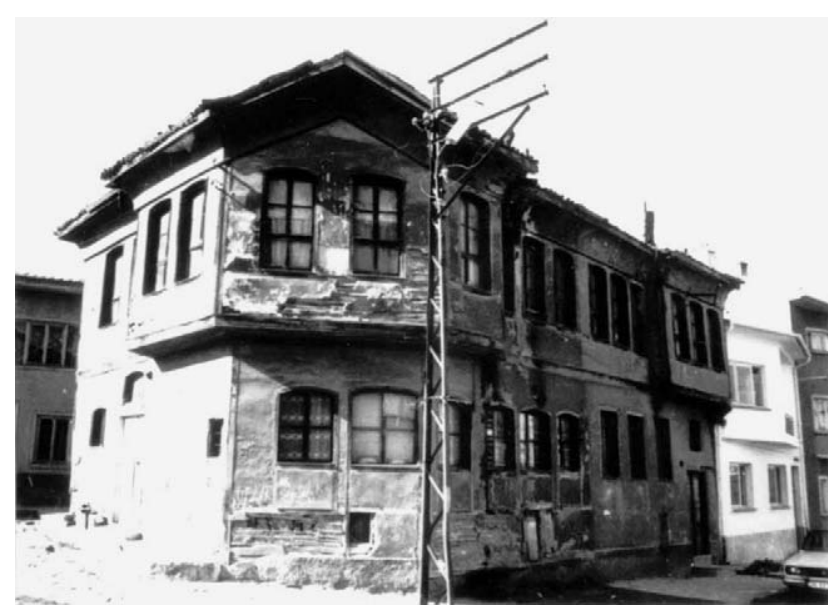

Fig. 10. A house in group "A".

All the traditional plan elements are graded. Higher grades are given to the traditional plan elements that are seen in a few houses and lower grades are given to the elements that are seen in many houses.
Four points are given to elements that exist in not more than five houses: old staircase in five houses, decorated door in four houses and kiosk in four houses. Three points are given to elements that exist in approximately 6-11 houses: decorated cupboard in 10 houses, divan in 10 houses and 'lambalik' (a decorative niche in the wall) in 9 houses. Two points are given to elements that exist in approximately $12-31$ houses: simple cupboard in 31 houses, 'yüklük' (a kind of cupboard) in 18 houses, 'gusulhane' (a kind of bath in the cupboard) in 16 houses, fireplace in 16 houses and decorated ceiling in 13 houses.

Consequently, if the final grade is between 0 and 15 , the house is classified in D group; 16-50, C group; 51-90, B group; 91-204, A group in its internal architectural value.

It can be criticized that the structural condition and the age of the building are not taken into account in the evaluation. In such an architectural evaluation, it is necessary to give more points to the houses, which are historically older. Being historically older is a positive factor. In this study, the construction dates of the houses are not exactly determined. However, it is intended to make an assumption with the help of the interior and exterior characteristics. It is considered that the examples whose facade orders and elements are simpler will define the older ones and the examples that have rich facade elements will define the ones of later times. Nevertheless common features in dimensions and details of the architectural elements exists. According to the verbal information obtained from older people of the area, upper class had built houses with rich facade order and lower class had built simple ones. And it is asserted by some inhabitants that there are houses without definite architectural characteristics but that are as old as traditional ones.

In this study, the age of the buildings was not taken into consideration since misleading results would occur in historical evaluation, which would be performed with the help of the assumptions based on architectural characteristics.

The evaluation about the structural condition is not taken into consideration either, since the traditional houses do not have severe statically structural problems; in other words, these problems necessitate intense material repairs. However, when the architectural evaluation is carried out in such a zone that has serious statically structural problems, these should be considered as negative factors.

\section{Conclusion}

This paper has aimed to propose an alternative method for the architectural evaluation of traditional houses in historical sites subjected to conservation in 
Table 2

The criteria and the grades for the internal evaluation of traditional houses

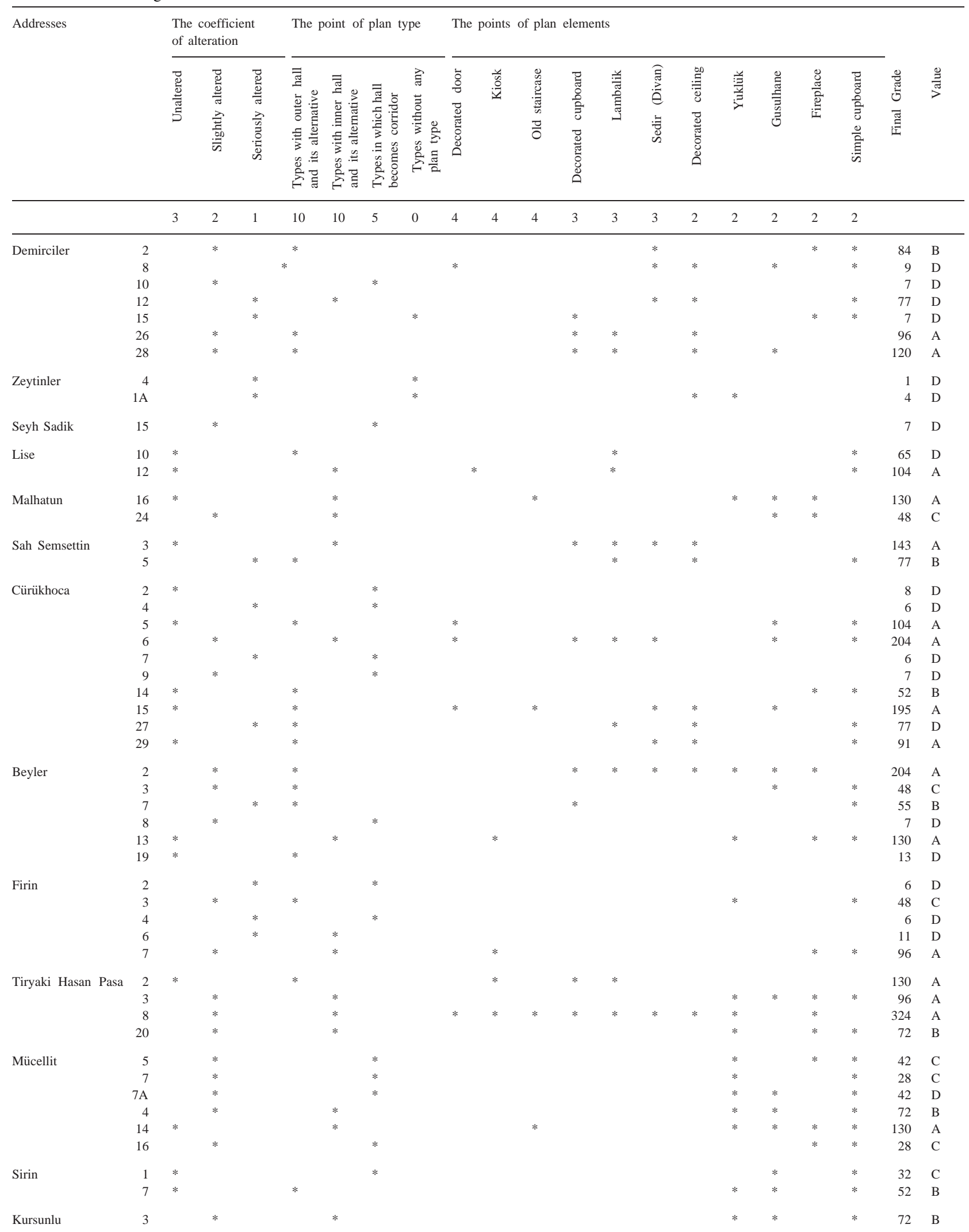


Table 2 (continued)

\begin{tabular}{|c|c|c|c|c|c|c|c|c|c|c|c|c|c|c|c|c|c|c|c|c|c|}
\hline \multirow[t]{2}{*}{ Addresses } & & \multicolumn{3}{|c|}{$\begin{array}{l}\text { The coefficient } \\
\text { of alteration }\end{array}$} & \multicolumn{4}{|c|}{ The point of plan type } & \multicolumn{11}{|c|}{ The points of plan elements } & \multirow[b]{2}{*}{ 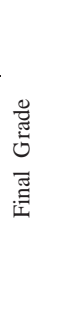 } & \multirow[b]{2}{*}{$\frac{9}{\frac{\pi}{\nu}}$} \\
\hline & & 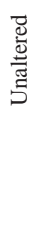 & 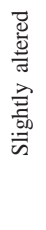 & 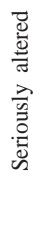 & 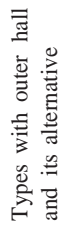 & 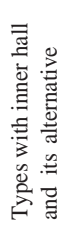 & 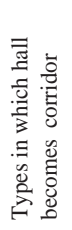 & 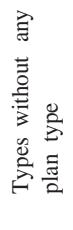 & 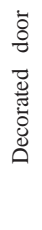 & 窇 & 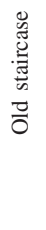 & 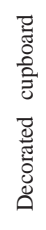 & 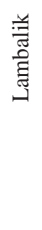 & 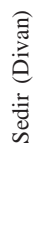 & 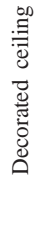 & 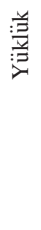 & 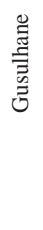 & 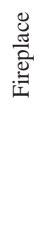 & 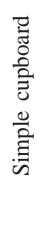 & & \\
\hline & & 3 & 2 & 1 & 10 & 10 & 5 & 0 & 4 & 4 & 4 & 3 & 3 & 3 & 2 & 2 & 2 & 2 & 2 & & \\
\hline & 5 & $*$ & & & & & * & & & & & & & & $*$ & & & & $*$ & 32 & $\mathrm{C}$ \\
\hline & 13 & & & $*$ & & & & $*$ & & & & $*$ & & & $*$ & & & & $*$ & 7 & $\mathrm{D}$ \\
\hline & 18 & & $*$ & & $*$ & & & & & & & & & & & & & & & 12 & $\mathrm{D}$ \\
\hline & 33 & & $*$ & & $*$ & & & & & & & & & & & & & & & 12 & $\mathrm{D}$ \\
\hline \multirow[t]{4}{*}{ Sehabettin } & 23 & & $*$ & & & & * & & & & & & & & & & & $*$ & $*$ & 32 & $\mathrm{C}$ \\
\hline & 27 & & $*$ & & & $*$ & & & & & & & & & & $*$ & & $*$ & $*$ & 72 & B \\
\hline & 29 & & & $*$ & & & $*$ & & & & & & & & & & & & & 6 & $\mathrm{D}$ \\
\hline & 31 & & & $*$ & & & $*$ & & & & & & & & & & & & & 6 & D \\
\hline
\end{tabular}

Turkey. The presented method illuminates the systematic way to evaluate architectural features belonging to historical sites whose conservation plans are to be prepared.

The validity of the method can be tested through further applications in similar sites. It is thought that such critical tests involving the above-described analytical gradation will result in correct determination of the architectural values belonging to traditional houses in Turkish historical sites. These values are original facade orders, plan types, architectural elements and their overall contribution to the historic environment. The determination will be followed by a classification leading to four different value groups A-D. This grouping will be advantageous while determining decisions for conservation. However, it should be underlined that these value groups will not necessarily match with certain intervention types. Nevertheless, different technique teams may be organized as responsible for these various value groups.

The importance of this type of grouping is determining the potentials of architectural features in the buildings, which constitute the historical environment. Its benefits at the implementation phase are as follows:

- The buildings in the same group will present similar working density. Then, phasing in the implementation will be possible. For example, a standard working process can be developed.

- The preliminary data, which will illuminate the details of the restoration projects of the buildings, will be provided.

- A systematic approach in the determination of the specialized team and the required equipment can be supplied.
- It can be useful for preparing working programme determining the required time and cost.

As a result, the expected benefit from this research is to provide data in order to create a systematic working process in the conservation plans.

\section{Acknowledgements}

I would like to express my thanks to the referees for their helpful comments on this paper.

\section{References}

[1] Worskett R. The character of towns: an approach to renewal. London: Architectural Press; 1969.

[2] Dobby A. Conservation and planning. London: Hutchinson; 1978.

[3] Kain R. Planning for conservation. London: Mansell; 1981.

[4] Fitch JM. Historic preservation: curatorial management of the built world. New York: McGraw Hill; 1982.

[5] Binney M. Our vanishing heritage. London: Arlington Books; 1984.

[6] Lichfield N. Economics in urban conservation. Cambridge: Cambridge University Press; 1988.

[7] Tunbridge JE, Ashworth GJ. Dissonant heritage: the management of the past as a resource in conflict. Chichester: Wiley; 1996.

[8] Tiesdell S, Oc T, Heath T. Revitalizing historic urban quarters. Oxford: Architectural Press; 1996.

[9] Healey P. Collaborative planning: shaping places in fragmented societies. London: Macmillan; 1997.

[10] Tyler N. Historic preservation: an introduction to its history, principles and practice. New York: W.W. Norton; 2000.

[11] Marks R. Conservation and community: the contradictions and ambiguities of tourism in the stone town of Zanzibar. Habitat International 1996;20(2):265-78. 
[12] Townshend T, Pendlebury J. Public participation and the conservation of historic areas: case-studies from the North-east of England. Journal of Urban Design 1999;4(3):313-31.

[13] Pendlebury J, Townshend T, Gilroy R. The conservation of English cultural built heritage: a force for social inclusion? International Journal of Heritage Studies 2004;10(1):11-31.

[14] Nijkamp P. Quantity and quality: evaluation indicators for our cultural-architectural heritage. In: Coccossis H, Nijkamp P, editors. Planning for our cultural heritage. Aldershot: Avebury; 1995. p. 17-37.

[15] Carter RW, Bramley R. Defining heritage values and significance for improved resource management: an application to Australian tourism. International Journal of Heritage Studies 2002;8(3): 175-99.
[16] Texier C. L'Asie Mineure, géographique, historique et archéologique des provinces et des villes de la chersonnése d'Asie. Paris; 1882.

[17] Ainsworth WF. Travels and researches in Asia Minor, Mesopotamia, Chaldea and Armenia. London: 1842.

[18] Cuinet V. La Turquie d'Asie. Paris: 1894.

[19] Darkot B. Eskișehir. In Islam ansiklopedisi, vol. 4, Istanbul; 1964. 384-7.

[20] Kuban D. The Turkish hayat house. Istanbul: Eren Yayincilik; 1995.

[21] İpekoğlu Acar B. Eskișehir Odunpazarı, Pașa, Orta, Akcami mahalleleri tesbit ve değerlendirme çalışmalarının yöntem ve sonuçları (Methods and results of survey, analysis and evaluation studies in Eskișehir Odunpazarı, Pașa, Orta, Akcami districts). Türk Etnografya Dergisi 1988;18:153-211. 